\title{
Production of Biogas from Co-Digestion of Cow Dung, Saw Dust and Maize Husk
}

\author{
Akindele Oyetunde Okewale, Felix Omoruwou, Christiana Edward Anih \\ Chemical Engineering Department, College of Technology, Federal University of Petroleum Resources, \\ Effurun, Nigeria \\ Email: oketunde2001@yahoo.com
}

How to cite this paper: Okewale, A.O. Omoruwou, F. and Anih, C.E. (2018) Production of Biogas from Co-Digestion of Cow Dung, Saw Dust and Maize Husk. Advances in Chemical Engineering and Science, 8, 113-123.

https://doi.org/10.4236/aces.2018.83008

Received: January 10, 2018

Accepted: June 11, 2018

Published: June 14, 2018

Copyright (c) 2018 by authors and Scientific Research Publishing Inc. This work is licensed under the Creative Commons Attribution International License (CC BY 4.0).

http://creativecommons.org/licenses/by/4.0/

\begin{abstract}
The co-digestion of cow dung, with maize husk for biogas production at laboratory scale was investigated. The study was carried out at a temperature range of $24^{\circ} \mathrm{C}-30^{\circ} \mathrm{C}$ and $\mathrm{pH}$ range of $5.5-6.5$ for a period of 60 days with a total solid concentration of $7.4 \%$ in the digester sample (fermentation slurry). Water displacement method was used to collect the biogas produced which was subsequently measured. $444.8 \mathrm{~mL}$ was the cumulative biogas yield at the end of 60 days retention time in the digester 1, which comprised of cow dung, maize husk, and water. Digester 2, which is made up of sawdust, cow dung, and water produced negligible biogas at the end of 60 days of the experiment. $\mathrm{X}-\mathrm{RF}$ analysis revealed high presence of elements like silica, aluminium oxides, and aluminium oxides in cow dung, maize husk, and sawdust respectively. The preponderance of alkanes and methyl group inmaize husk makes it to produce biogas compared to saw dust as shown by the Fourier transform infrared spectroscopy (FTIR) that was carried out to identify the various functional groups. The potential of maize husk to produced biogas was also established. The kinetic modeling shows that there was an increase in biogas yield as the retention time increases as depicted by the linear model.
\end{abstract}

\section{Keywords}

Sawdust, Biogas, Cow Dung, Maize Husk, X-Ray Fluorescence, FTIR

\section{Introduction}

Energy is a basic tool for development, the dependence of man on fossil fuels as a primary energy sources has led to global climate change, environment degradation and human health problem [1]. These depletion and environmental degradation gave a boost to the renewable and sustainable energy alternatives to the 
non-renewable fossil fuel. Maize husk is an agricultural waste that can be transformed either by chemical and or biological means. Agricultural waste from animals such as poultry droppings, cow dung, and swine dung usually produce obnoxious odour and constitutes environmental problems for the people living around the area where such waste are dumped.

These animal wastes have been found to consist of exploitable gas and energy which can be obtained by a process called bio-menthanisation and the gas produced can be used as a source of energy or if burnt directly could be used for heat effect [2]. Bio-waste can be degraded anaerobically in a biogas digester to produce bio-gas and other gas. Maize husk which is a waste from maize, a cereal crop grown widely throughout Nigeria and the world at large, this waste from maize is left behind after harvest. The disposed maize wastes have some positive and negative effects on the environment but like other waste are indiscriminately left on farm lands to be mineralized and used by other crops. Moreover, maize husk is found in non-farm lands like schools, homes, market, etc. It poses a serious environmental threat to human beings but if properly recycled and treated an aerobically could yield biogas. Biogas refers to gas produced by biological breakdown of organic matter in the absence of oxygen. Biogas formation can occur naturally in swamps, marine sediment and water logged soils, rice field, deep bodies of water, sanitary landfills and even in the digestive system of ruminants, and termites [3].

[4], studied the biogas production potential of un-extracted nutrient-rich elephant grass. The work revealed that crushed un-extracted elephant grass straw is biodegradable by mixed microorganisms as effectively as by pure cultures. The work also showed that support with potato dextrose agar as well as nutrients such as urea is essential for attaining substantial gas yield. In conventional mesophilic biogas plants the retention time is 30 to 50 days on an average. The retention time in mesophilic biogas plants has been found to decrease below 15 days in large scale implementation [5]. Co-digestion is the simultaneous digestion of more than one type of waste in the same unit [6]. Advantages include better digestibility, enhanced biogas production/methane yield arising from availability of additional nutrients, as well as a more efficient utilization of equipment and cost sharing [7] [8]. Results of co-digestion of food waste and dairy manure in a two-phase digestion system conducted at laboratory scale showed that the gas production rate of co-digestion was enhanced by $0.8-5.5$ times as compared to the digestion with dairy manure alone [9]. Temperature has a significant effect on digestion rate with most processes occurring at temperatures in the mesophilic temperature range $75-100^{\circ} \mathrm{F}$, but anaerobic digestion also can be carried out at the thermophilic temperatures $\left(125-140^{\circ} \mathrm{F}\right)$. It is well known fact that the thermophilic is more efficient than the mesophilic in terms of retention time, loading rate, and nominal biogas production but it needs a higher energy input, more expensive technology, and greater sensitivity to operating and environmental variables, which makes the process more prob- 
lematic than mesophilic digestion [10]. Biogas is a promising alternative source of energy to Nigerians compare to the high cost of energy from fossil fuel that is available to the common man in Nigeria and non-availability of this fossil fuel energy source. It is environmentally friendly and cheap to produce by almost every Nigerian. Simulation of biogas, methane and hydrogen production has been reported by [11] and the modeling of biogas production from anaerobic digestion has been based on kinetic models. Since biogas production is associated with micro-organism playing a paramount role in the process, kinetic models particularly the first order kinetics were commonly applied to simulate the anaerobic biodegradation. Like the microbial growth phase, biogas production rate which shows a rising limb and decreasing limb which can be indicated by exponential and linear equation [12]. There is little or no information in literature towards the production of biogas from maize husk; this necessitated the present work which examines the co-digestion of cow dung, with maize husk and saw dust in mesophilic condition.

\section{Materials}

Cow dung was procured from government approved Abattoir in Agbarho, Delta State. The maize husk was gotten from a cabbage site in Ugbomoro Community while the saw dust was obtained from Uti Sawmill in Effurun, Uvwie Local Government Area of Delta State. Sodium chloride $(\mathrm{NaCl})$, tetra oxo sulphate (VI) acid $\left(\mathrm{H}_{2} \mathrm{SO}_{4}\right)$, Buckner flask $(500 \mathrm{~mL})$, conical flasks $(500 \mathrm{ml})$, mercury in glass thermometer (range between $-10^{\circ} \mathrm{C}-100^{\circ} \mathrm{C}$, with an accuracy of $\pm 0.1^{\circ} \mathrm{C}$ ), digital $\mathrm{pH}$ meter (HANNA model $\mathrm{pH}-211$ ), distilled water, delivery tubes, corks, measuring cylinder $(200 \mathrm{~mL})$, muffle furnace, Oven (Genlab oven model, Mino/75/f), connecting tubes, mortar and pestle and weighing balance (model $\mathrm{BH} 600$ ) with an accuracy of $0.01 \mathrm{~g}$ were used for the biogas produced.

\subsection{Characterization of Substrates}

\subsubsection{Pre-Treatment of Both Substrates}

Maize husk and cow dung were sun dried for three days to remove moisture from them and thereafter oven dried at $110^{\circ} \mathrm{C}$ for 8 hours. It was then grinded and sieved into small particle size $<2 \mu \mathrm{m}$.

\subsubsection{Determination of $\mathrm{pH}$}

A measured quantity of the sample slurry was transferred into a beaker. The slurry was agitated and left for 24 hours at room temperature. The $\mathrm{pH}$ meter (HANNA model pH-211) was then used to measure the slurry $\mathrm{pH}$ [13].

\subsubsection{Determination of Moisture Content}

$10 \mathrm{~g}$ of the pre-treated sample was weighed initially in petri dish which was placed in an oven at $110^{\circ} \mathrm{C}$. The weight was taking after every 10 minutes until a constant weight was obtained (final weight). The moisture content was determined by using the Equation (1): 


$$
\% \text { Moisture content }=\frac{\text { Initial weight }- \text { final weight }}{\text { Initial weight }} \times 100
$$

The moisture content was determined using standard test ASTMD 2867-91 [14].

\subsubsection{Determination of Volatile Matter}

$5 \mathrm{~g}$ of the samples were weighed initially in petri dishes and placed in a muffle furnace at $500^{\circ} \mathrm{C}$ for 4 hours. The samples were allowed to cool down in a desiccator and re-weighed again. The lost in weight is now the volatile matter present in the samples using Equation (2).

$\%$ Volatile Matter

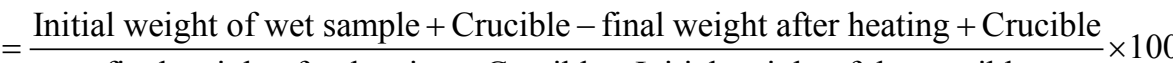
final weight after heating + Crucible - Initial weight of the crucible

\subsubsection{FTIR Spectroscopy}

The structural organization of the substrates was investigated to identify the functional groups presents. The adsorbents were examined using SHIMADZU FTIR-8400S spectrophotometer with the range $500-4000 \mathrm{~cm}^{-1}$. $\mathrm{KBr}$ was used as background material in the analysis.

\subsubsection{X-Ray Fluorescence Analysis}

The elemental compositions of the cow dung and maize husk were analyzed using the X-ray fluorescence.

\subsection{Experimental Procedure}

Laboratory scale production was used in the production of biogas. All apparatus were properly washed with soap solution, distilled water, and allowed to dry by standing over night in the laboratory. A set of Buckner flasks $(500 \mathrm{ml})$ was used as digester for each of the sample. Another set of Buckner flasks $(500 \mathrm{ml})$ was used. It contained an acidified brine water solution and was connected to the digester by means of a connecting tube and also, on the other side, connected to a conical flask by means of a connecting tube. Thus, the biogas produced in the digester by fermented slurry (sample) passed through the connecting tube to the Buckner flask containing acidified brine solution. The pressure of the biogas produced caused a displacement of the acidified brine water solution through the connecting tube on the other side of the conical flask. The amount of water displaced was then measured as the volume of biogas produced. The digester was operated at ambient temperatures. $7.4 \%$ total solid concentration was used in each of the digester. The first digester which consists of maize husk, cow dung and water were mixed together by mass ratio $5 \mathrm{~g}$ : $15 \mathrm{~g}$ : $250 \mathrm{~g}$ respectively. The second digester which is made up of saw dust; cow dung and water were mixed together by mass ratio 5 g: 15 g: 250 g respectively. The slurry was stirred manually, and readings taken within five days interval while temperature reading was taken in the morning and evening throughout the period of the study. The experimental set-up is shown in Figure 1. 


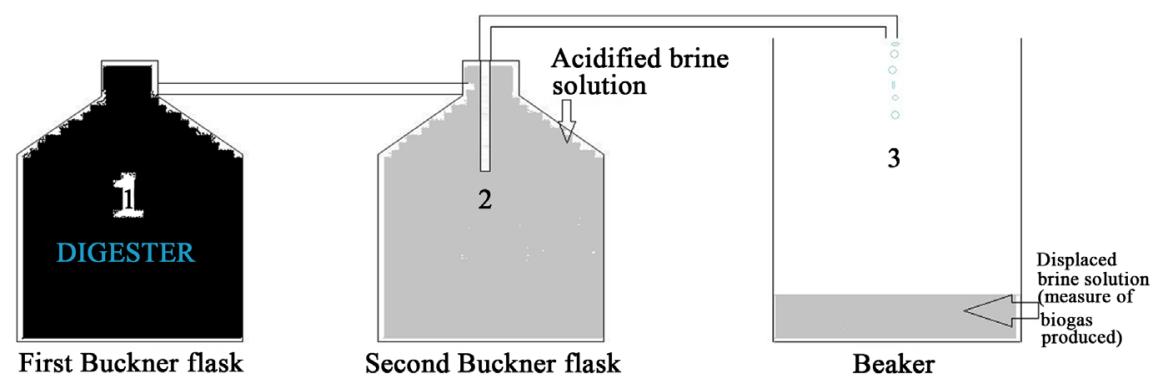

Figure 1. The experimental set-up for the biogas production.

\subsection{Linear Kinetic Models of Biogas Produced}

Biogas production rates from co-digestion of cow dung, maize husk and sawdust was simulated using linear plot. The ascending and descending limbs could be expressed in this model [12] reported that ascending and descending limb of biogas production rate can be expressed by the linear Equation (3) below:

$$
y=a+b t
$$

where $y$ is biogas production rate in $\mathrm{ml} / \mathrm{gm} /$ day, $t$ is time in days for the digestiona $(\mathrm{ml} / \mathrm{gm} /$ day $)$ and $b(\mathrm{ml} / \mathrm{gm} /$ day $)$ are constant obtained from the intercept and slope of the plot of $y$ against $\mathrm{t}$ in $\mathrm{ml} / \mathrm{gm} /$ day.

\section{Results and Discussion}

It can be seen from Tables 1-4 that cow dung has high amount of silica in its element which also suggest that this element also contributes to the digestion of microorganisms for the biogas production. Aluminium oxide is the main element present in both maize husk and sawdust.

\subsection{Fourier Transform Infrared (FTIR) Analysis}

As shown in Figure 2, the broad band with frequency $\left(3421.6 .402-3600 \mathrm{~cm}^{-1}\right)$ exhibited RO-H (Alcohol) wide branded band while the broad band (2900 - 2700 $\mathrm{cm}^{-1}$ ) exhibited aldehyde. Thiol (S-H) bending, huge band was shown in broad band $\left(2600-2550 \mathrm{~cm}^{-1}\right)$. The broad band frequency of $\left(1670-1615 \mathrm{~cm}^{-1}\right)$ shows that $\mathrm{C}=\mathrm{C}$ stretch is present. At a broad band of $\left(1600-1590 \mathrm{~cm}^{-1}\right) \mathrm{C}=\mathrm{C}$ stretch was revealed. At broad band $\left(810-760 \mathrm{~cm}^{-1}\right) \mathrm{C}-\mathrm{H}$ bend was observed [15]. The highest peak with frequency $1870.32 \mathrm{~cm}^{-1}$ suggests that carbonyl compound is the main functional group in the cow dung sample.

\subsection{FTIR of Maize Husk}

It can be seen in Figure 3 that frequency $\left(3550-3000 \mathrm{~cm}^{-1}\right)$ depict RO-H (Alcohol) wide broad band. $\mathrm{C}-\mathrm{H}$ stretch of $\mathrm{CHO}$ (carboxylic acid) group very wide band was shown with frequency $\left(2900 \mathrm{~cm}^{-1}\right.$ and $\left.2700 \mathrm{~cm}^{-1}\right)$ while $(2820-2780$ $\mathrm{cm}^{-1}$ ) frequency corresponds to $\mathrm{C}-\mathrm{H}$ stretch of $-\mathrm{N}-\mathrm{CH}_{2}$. The broad band (1725 $1700 \mathrm{~cm}^{-1}$ ) correspond to $\mathrm{C}=\mathrm{O}$ stretch ketone $\mathrm{R}_{2} \mathrm{C}=\mathrm{O}$. The broad band of 1650 $1590 \mathrm{~cm}^{-1}$ revealed primary amine, $\mathrm{NH}$ bond. The broad band of $\left(1465-1415 \mathrm{~cm}^{-1}\right)$ 


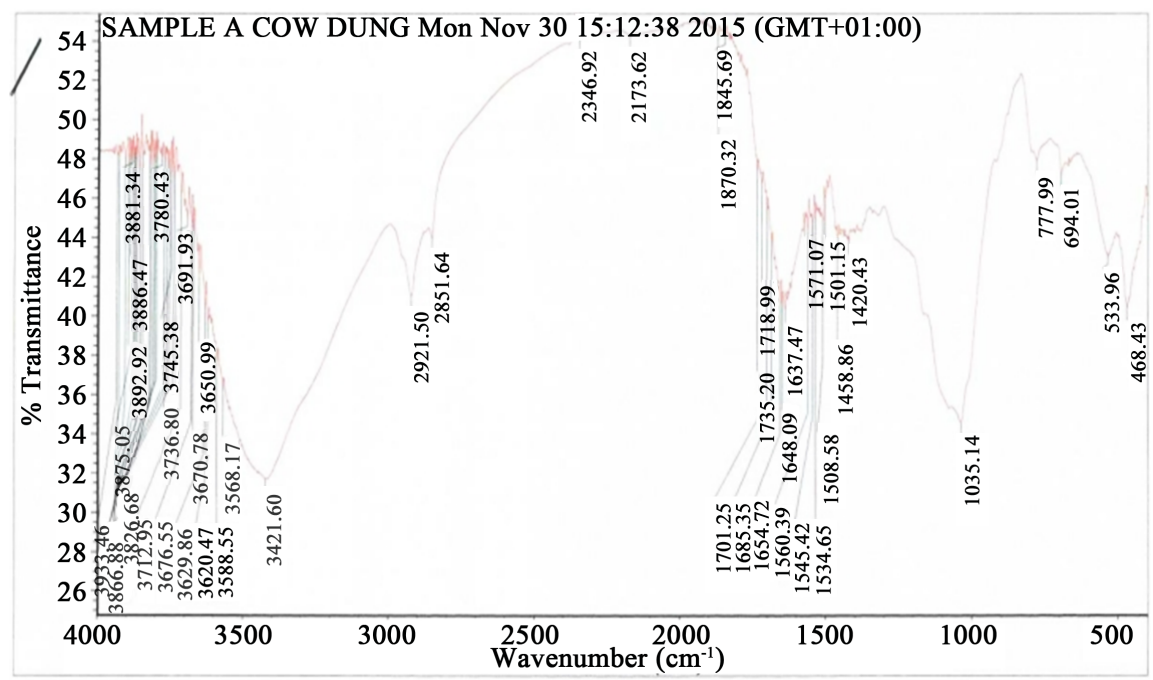

Figure 2. FTIR spectra of cow dung.

Table 1. Characterization of cow dung, maize husk and sawdust.

\begin{tabular}{cccc}
\hline Properties & Cow dung & Maize husk & Saw dust \\
\hline Moisture content (\%) & 5.5 & 5.9 & 4.4 \\
Volatile matter (\%) & 89 & 92.4 & 94.3 \\
$\mathrm{pH}$ & $5.71-7.2$ & $5.96-6.5$ & $5.5-6.3$ \\
Particle size & $<2 \mu \mathrm{m}$ & $<2 \mu \mathrm{m}$ & $24-30$ \\
Temperature $\left({ }^{\circ} \mathrm{C}\right)$ & $24-30$ & $24-30$ & 82 \\
$\mathrm{C} / \mathrm{N}$ & 19 & 60 & 0.7 \\
$\mathrm{~N}(\%)$ & 2.4 & 0.09 & 1.7 \\
TPH (mg/kg) & 4901.4 & 177.8 & 50.4 \\
\hline
\end{tabular}

Table 2. Elemental compositions of cow dung.

\begin{tabular}{cccccccccc}
\hline Element & $\mathrm{Na}_{2} \mathrm{O}$ & $\mathrm{MgO}$ & $\mathrm{Al}_{2} \mathrm{O}_{3}$ & $\mathrm{SiO}_{2}$ & $\mathrm{P}_{2} \mathrm{O}_{5}$ & $\mathrm{~K}_{2} \mathrm{O}$ & $\mathrm{CaO}$ & $\mathrm{TiO}_{2}$ & $\mathrm{Fe}_{2} \mathrm{O}_{3}$ \\
\hline Concentrations (\%) & 1.521 & 0.871 & 20.034 & 21.936 & 3.026 & 2.672 & 2.138 & 0.631 & 3.456
\end{tabular}

Table 3. Elemental Compositions of Maize husk.

\begin{tabular}{cccccccccc}
\hline Element & $\mathrm{Na}_{2} \mathrm{O}$ & $\mathrm{MgO}$ & $\mathrm{Al}_{2} \mathrm{O}_{3}$ & $\mathrm{SiO}_{2}$ & $\mathrm{P}_{2} \mathrm{O}_{5}$ & $\mathrm{~K}_{2} \mathrm{O}$ & $\mathrm{CaO}$ & $\mathrm{TiO}_{2}$ & $\mathrm{Fe}_{2} \mathrm{O}_{3}$ \\
\hline Concentrations (\%) & 2.140 & 1.267 & 20.373 & 12.851 & 1.741 & 3.085 & 0.842 & 0.596 & 6.593
\end{tabular}

Table 4. Elemental compositions of sawdust.

\begin{tabular}{cccccccccc}
\hline Element & $\mathrm{Na}_{2} \mathrm{O}$ & $\mathrm{MgO}$ & $\mathrm{Al}_{2} \mathrm{O}_{3}$ & $\mathrm{SiO}_{2}$ & $\mathrm{P}_{2} \mathrm{O}_{5}$ & $\mathrm{~K}_{2} \mathrm{O}$ & $\mathrm{CaO}$ & $\mathrm{TiO}_{2}$ & $\mathrm{Fe}_{2} \mathrm{O}_{3}$ \\
\hline Concentrations (\%) & 0.862 & -0.409 & 20.498 & 11.333 & 1.027 & 0.779 & 0.875 & 0.594 & 6.599
\end{tabular}




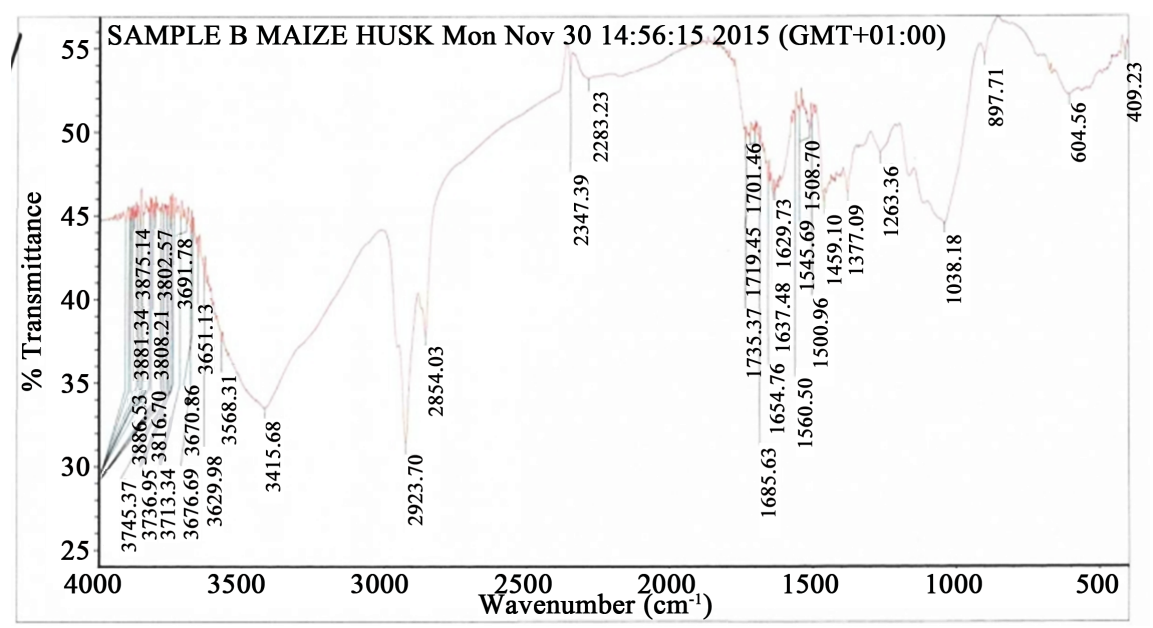

Figure 3. FTIR of maize husk.

showed the presence of C-H bend Alkyl group. The broad band $810-760 \mathrm{~cm}^{-1}$ shows the presence of $\mathrm{C}-\mathrm{H}$ bend. The presence of the alkanes and methyl group makes the maize husk to produce biogas compared to saw dust.

\subsection{FTIR of Sawdust}

As shown in Figure 4 the $\mathrm{OH}$ (secondary Alcohol) stretch broad band was shown with frequency $\left(3626.52 \mathrm{~cm}^{-1}\right.$ ) while $3391.07 \mathrm{~cm}^{-1}$ indicates normal polymeric "O-H" stretch. None bounded hydroxyl group O-H stretch, primary alcohol was shown in broad band $3646.03 \mathrm{~cm}^{-1}$ (Coates, 2000). C-H, SP ${ }^{3}$ band was exhibited between $\left(2852.95-2922.82 \mathrm{~cm}^{-1}\right)$ while $\mathrm{C}=\mathrm{O}$ huge band was noticed at broad band $\left(1651.55 \mathrm{~cm}^{-1}\right.$ and $\left.1732.37 \mathrm{~cm}^{-1}\right)$. The highest intensity (peak) with frequency $2149.60 \mathrm{~cm}^{-1}$ suggests that $\mathrm{C}=\mathrm{C}$, short and narrow is the main functional group in the hardwood sawdust.

\subsection{Cumulative Biogas Production}

Figure 5 showed the cumulative biogas produced from the digester 1 for 60 days of fermentation. There was no production in the two digesters for the first four days of fermentation this can be explained as a result of the inoculum that is either in the lag phase or methanogens undergoing a metamorphic growth process by consuming methane precursors produced from the initial activity as reported by [16]. Production started on the $5^{\text {th }}$ day in the digester 1 with a volume of 1.0 $\mathrm{mL}$ in digester 1 and none in digester 2 . There was a steady increase in biogas production till there was a sudden increase in biogas production for thedigester1 within a retention time of 35 - 60 days while there was no biogas production in digester 2. This sudden increase is as a result of an exponential increase in micro-organisms which leads to an increase in fermentation rate and corresponding increase in biogas production. The initial $\mathrm{pH}$ for the slurry in digester 1 is 5.96 while 5.50 is the initial $\mathrm{pH}$ for digester 2 . This observed $\mathrm{pH}$ change may be due to the high volatile solids in the saw dust and maize husk which were transformed into a volatile fatty acids and other acidic metabolites during acidogensis 


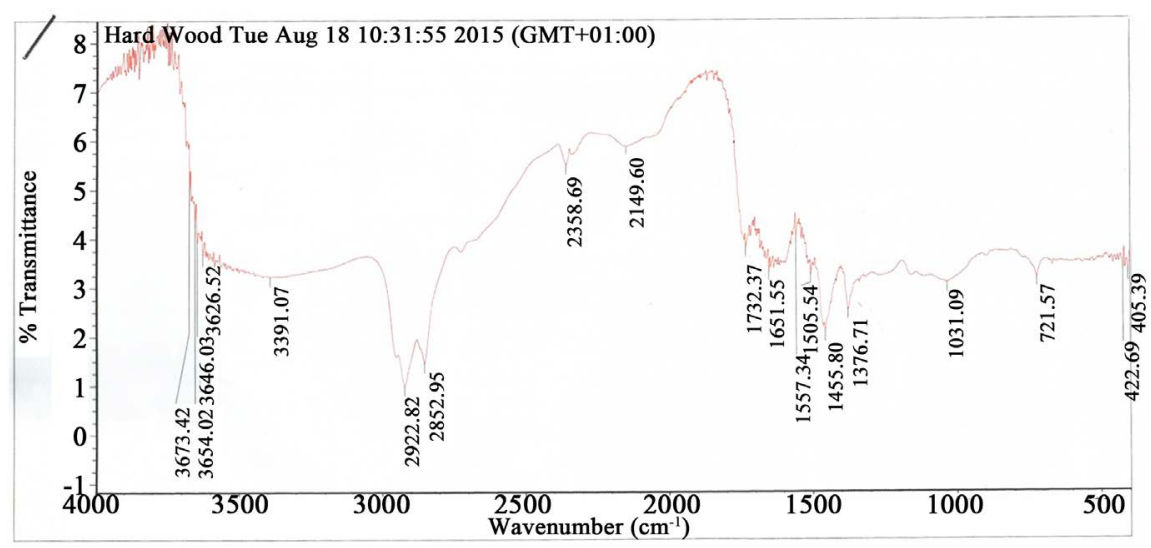

Figure 4. FTIR of sawdust.

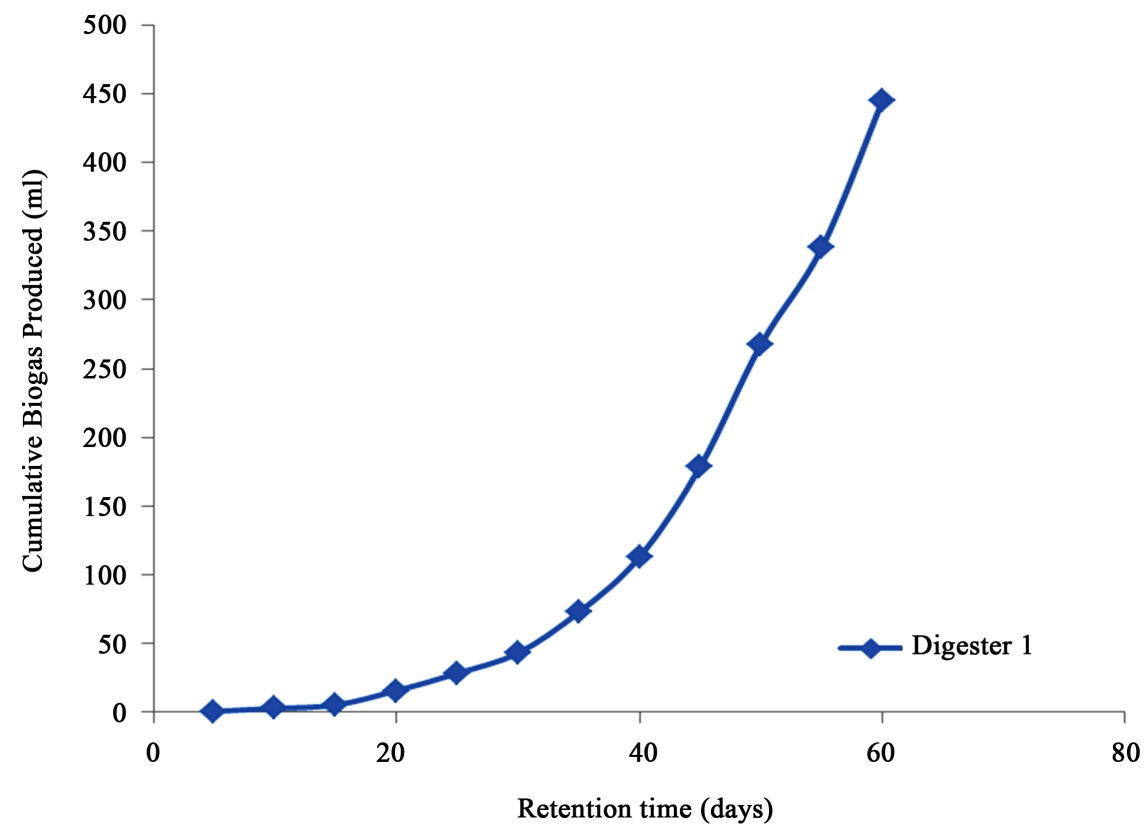

Figure 5. Cummulative biogas produced with retention time.

by the activities of the facultative aerobes and aerobes that were metabolized subsequently by the methanogenic bacteria to generate biogas [17] [18] [19]. The value of the $\mathrm{pH}$ increased in the two digesters as retention time (days) increased throughout the period of biogas production. As the $\mathrm{pH}$ start to increase the biogas production rate also increase with the retention time. This increased biogas yield with increase in $\mathrm{pH}$ may be due to increase in metabolic activity within the microorganisms present in the digester.

As shown in Figure 6 the slurry temperature range of $25^{\circ} \mathrm{C}-29^{\circ} \mathrm{C}$ was observed during the process of fermentation. The highest volume of biogas was observed for digester 1 at a temperature of $27^{\circ} \mathrm{C}$ while no biogas production was observed in digester 2. [20] [21], reported that ambient temperature affects the rate of digestion due to the outside walls of the digesters surface making direct contact with the atmosphere. The digester walls absorb or loose heat depending 
on the temperature gradient between the digester and its immediate environment. This indicated that seasons affect the rate of heat loss or gain from the digester which in turn affects the microbial activities in the slurry at each stage of fermentation [21].

It can be seen in Figure 7 that as the retention time increases rate of biogas produced also increases. The coefficient of correlation $\left(\mathrm{R}^{2}\right)$ shows that the correlation is a good one having a value of 0.8319; the plot suggests that it was an ascending limb since the value of $b$ is positive. The digester 1has constant $a$ and $b$ with a numerical value of $-1.1858 \mathrm{ml} / \mathrm{gm} /$ day and $0.0747 \mathrm{ml} / \mathrm{gm} /$ day respectively. It was established from the plot that biogas production rate will increase linearly with increase in time and after reaching a maximum point after sometime (days) it would decrease linearly to zero as retention time increases.

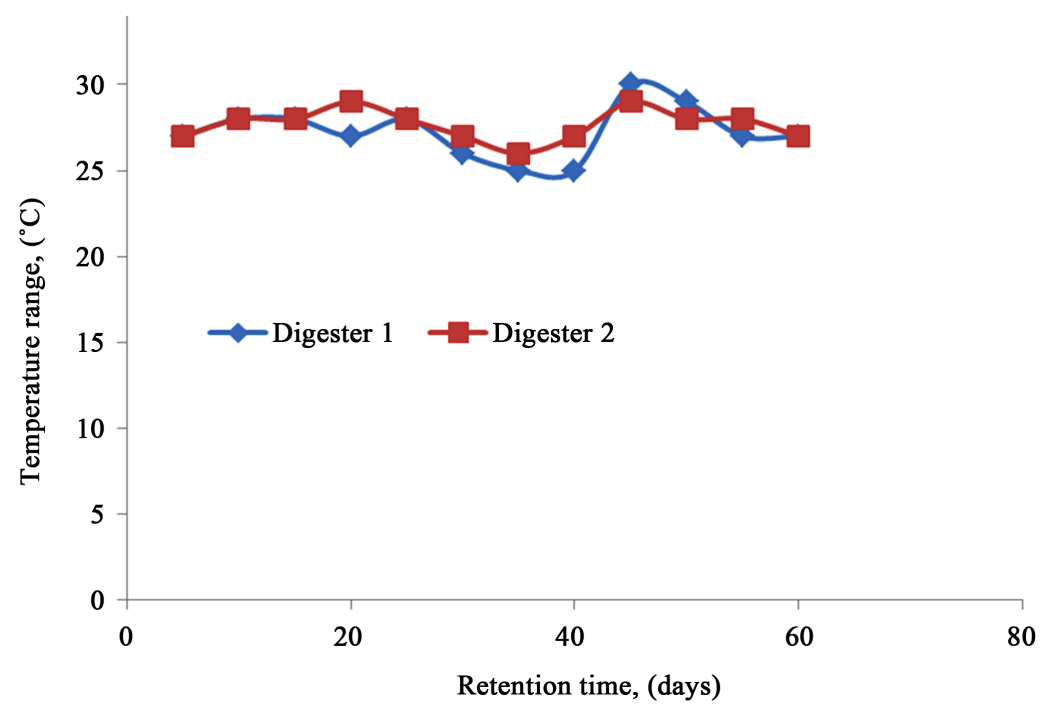

Figure 6. Temperature variation with retention time.

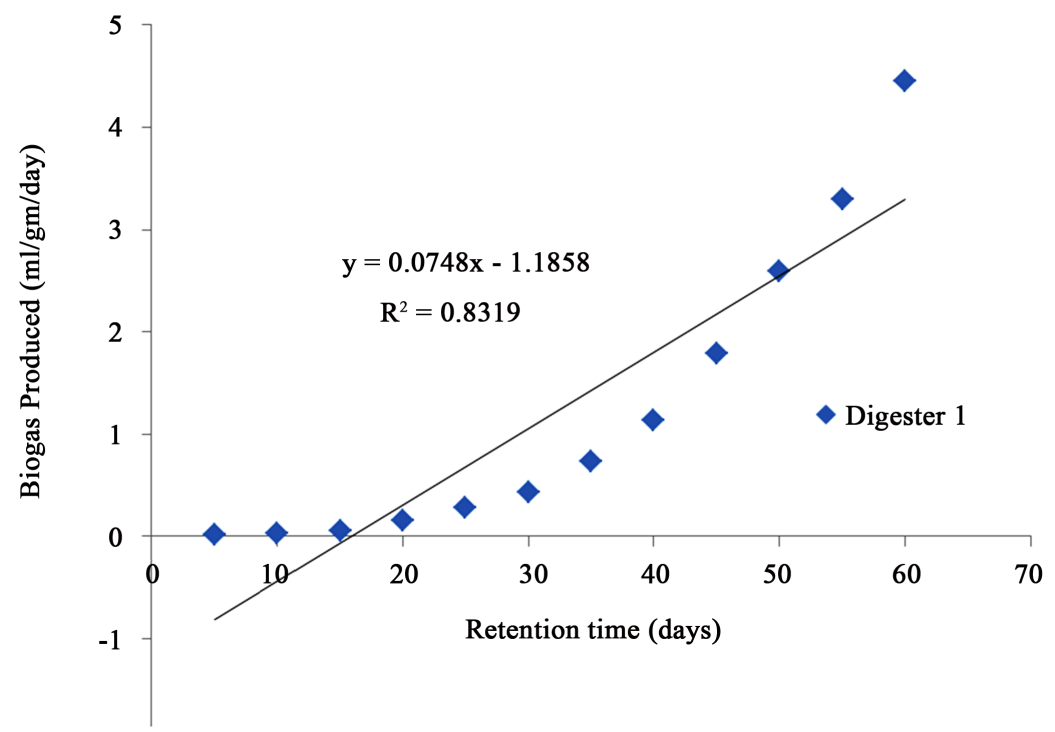

Figure 7. Linear model for biogas produced against retention time. 


\section{Conclusion}

Anaerobic digestion of maize husk, sawdust, and cow dung for biogas production was established in this work. The data obtained from the biogas produced fitted well to linear kinetic model. It was shown that the variation in temperature, $\mathrm{pH}$, and retention time had effect on the volume of biogas produced. The preponderance of alkanes and methyl group, and the lower number of carbon to nitrogen ratio in maize husk enables it to produce biogas compared to saw dust. This makes maize husk to be a good substrate for biogas production. The residue of this anaerobic digestion retains a rich fertilizer value of the initial plant waste products.

\section{References}

[1] Annushiya (2006) Anaerobic Digestion for Bioenergy from Agro Residues and Other Solid Wastes-An Overview of Science, Technology and Sustainability.

[2] Dupont and Accorsi (2006) Studies on Biochemical Changes in Maize Wastes Fermented with Aspergillus niger. Biokemistri, 19, 75-79.

[3] Singh, K.J. and Sooch, S.S. (2012) Comparative Study of Economics of Different Models of Family Size Biogas Plants for State of 10 Punjab. India Energy Conversion, 45, 1329-1341. https://doi.org/10.1016/j.enconman.2003.09.018

[4] Ekpenyong, K.I., Arawo, J.D.E., Arawo, A., Melaiye, M.M., Ekwenchi, H.A. and Abdullahi (1995) Biogas Production Potential of Unextracted, Nutrient-Rich Elephant-Grass Lignocellulose. Fuel, 74, 1080-1082. https://doi.org/10.1016/0016-2361(95)00057-C

[5] Kale, S. and Mehetre, S. (2006) Kitchen Waste Based Biogas Plant, Nuclear Agriculture and Biotechnology Division, Bhabha Atomic Research Centre, India.

[6] Agunwamba, J.C. (2001) Waste Engineering and Management Tool. Immaculate Publication Limited, Enugu.

[7] Parawira, W., Murto, M., Zvauya, R. and Mattiasson, B. (2004) Anaerobic Digestion of Solid Potato Waste Alone and in Combination with Sugar Beet Leaves. Renewable Energy, 29, 1811-1823. https://doi.org/10.1016/j.renene.2004.02.005

[8] Mshandete, A.M. and Parawira, W. (2009) Biogas Technology Research in Selected Sub-Saharan African Countries: A Review. African Journal of Biotechnology, 8, 116-125.

[9] El-Mashad, H.M. and Zhang, R. (2007) Co-Digestion of Food Waste and Dairy Manure for Biogas Production. Transactions on ASABE, 50, 1815-1822. https://doi.org/10.13031/2013.23945

[10] Aremu, M.O. and Agarry, S.E. (2012) Comparison of Biogas Production from Cow Dung and Pig Dung under Mesophilic Condition. International Refereed Journal of Engineering and Science, 1, 16-21.

[11] De Gioannis, G., Muntoni, A., Cappai, G. and Milia, S. (2009) Landfill Gas Generation after Mechanical Biological Treatment of Municipal Solid Waste: Estimation of Gas Generation Rate Constants. Waste Management, 29, 1026-1034. https://doi.org/10.1016/j.wasman.2008.08.016

[12] Kumar, S., Mondal, A.N., Gaikward, S.A., Devotta, S. and Singh, R.N. (2004) Qualitative Assessment of Methane Emission Inventory from Municipal solid Waste Disposal Sites: A Case Study. Atmospheric Environment, 38, 4921-4929. 
https://doi.org/10.1016/j.atmosenv.2004.05.052

[13] American Society for Testing and Materials: Annual Book of ASTM Standard (1996) Volume 15.01, Refractories, Carbon and Graphic Products, Activated Carbon, ASTM, Philadelphia.

[14] American Society for Testing and Materials (1991) Standard Test Methods for Moisture in Activated Carbon. ASTM Committee on Standards, Philadelphia.

[15] Coates, J. (2000) Interpretation of Infrared Spectra: A Practical Approach. In: Meyers, R.A., Ed., Encyclopedia of Analytical Chemistry, John Wiley and Sons Ltd., Chichester, 10815-10837.

[16] Lalitha, K., Swaminathan, K.R. and Bai, R.P. (1994) Kinetics of Biomethanation of Solid Tannery Waste and the Concept of Interactive Metabolic Control. Applied Biochemical Biotechnology, 47, 73-87. https://doi.org/10.1007/BF02788677

[17] Dennis, A. and Burke, P.E. (2001) Dairy Waste Anaerobic Digestion Handbook. Environmental Energy Company, Olympia.

[18] Latinwo, G.K. and Agarry, S.E. (2015) Modelling the Kinetics of Biogas Generation from Mesophilic Anaerobic Co-Digestion of Sewage Sludge with Municipal Organic Waste. Chemical and Process Engineering Research, 31, 43-53.

[19] Iyagba, E.I., Mangibo, I.A. and Mohammad, Y.S. (2009) The Study of Cow Dung as Co-Substrate with Rice Husk in Biogas Production. Scientific Research Essays, 4, 861-868

[20] Ukpai, P.A. and Nnabuchi, M.M. (2012) Comparative Study of Biogas Production from Cow Dung, Cow Pea, and Cassava Peeling Using 45 Litres Biogas Digester. Advances in Applied Science Research, 3, 1864-1869.

[21] Okewale, A.O., Omoruwuo, F. and Ojaigho, R.O. (2016) Alternative Energy Production for Environmental Sustainability. British Journal of Renewable Energy, 1, 18-22. 